\title{
Mental Health in Prison: Prevention from Suicide
}

\author{
Doïna D. Tesu-Rollier ${ }^{1,2}$, Mareike Wolf-Fédida ${ }^{1,2}$ \\ ${ }^{1}$ SPMR Prison Fleury-Mérogis, Paris, France \\ ${ }^{2}$ Psychology Department, Université Denis Diderot-Paris 7, Paris, France \\ Email: M14Wolf@aol.com
}

Received 13 June 2014; revised 11 July 2014; accepted 5 August 2014

Copyright (C) 2014 by authors and Scientific Research Publishing Inc.

This work is licensed under the Creative Commons Attribution International License (CC BY). http://creativecommons.org/licenses/by/4.0/

(c) (i) Open Access

\begin{abstract}
The risk of attempted suicide is approximately $70 \%$ at Fleury-Mérogis (France), the biggest prison in Europe. Prisoners' health includes mental health; therefore, suicide prevention is the aim of all persons working at Fleury-Mérogis. The current study presents specific information about suicide in prison and preventative actions that can be taken. Statistics make clear the probability of suicide risk in prison and the circumstances of risk. We also examined the concept of mental health in the environment of prison. Some examples from the prevention program at Fleury-Mérogis are presented to give an idea about the importance of structuring everyday life and working as a team. We summarize the arguments of the first suicide prevention program at Fleury-Mérogis started by Dr. Tesu-Rollier (Tesu-Rollier \& Coutanceau, 2007; Tesu-Rollier, 2013a, 2013b; Tyroge \& Albernhe, 1995).
\end{abstract}

\section{Keywords}

Mental Health, Prevention, Prison Fleury-Mérogis, Psychiatry, Suicide

\section{Introduction}

Fleury-Mérogis is the largest prison in France and it is overcrowded. In fact, it is the biggest prison in Europe. Suicide epidemics have always been a problem at Fleury-Mérogis since its creation in the early 70s. Indeed, prisoners' health seems to be mainly a mental health problem in this prison. Now, the buildings have aged and the prison has become more crowded. All persons working there are afraid of more violence because of this situation. The mental health of the prisoners is also impacted by the conditions of everyday life in this prison. As this situation has become worse, there is an imminent need for a program preventing suicide. 


\section{The Suicide Risk}

Prevention of suicide includes all kind of studies about risk prevention in the matter of hetero- and auto-aggression. Aggression and violence are related to mental health problems. In the matter of suicide risk, we never know whether murder begins by directing action to oneself or to another. Prisoners' health also means to prevent them from being aggressed and from being hurt, physically and mentally. All violent acts may remind the prisoner of incarceration, i.e., "that's why I am here". Punishment by the loss of liberty hurts much more when one is aggressed and humiliated. The prisoner feels as if they are being punished twice.

Suicide is about getting rid of somebody one cannot stand anymore. There is confusion about oneself and another. That is why other languages call suicide "murder of oneself”. For example in German, suicide is called Selbstmord. Indeed, murderers and all "blood crimes” have the highest rate of suicide (Allialaire \& Guedeney, 2001; Allilaire, \& Pelissolo et al., 2005; Allilaire, 2005; Coldefy, Faure, \& Prieto, 2002; Guillonneau, 2003; Prieto, 2004; Tesu-Rollier \& Coutanceau, 2006).

A psychiatrist from Fleury-Mérogis, Dr. D. D. Tesu-Rollier, was told by prisoners: "In jail, we think about escaping or about suicide... about our family too. But death and suicide are haunting our mind all the time”. She reminds us (Tesu-Rollier, 2013a, 2013b) that we are frequently confronted with unusual acts realized by our incarcerated patients. Harming oneself or another by cutting and swallowing sharp objects is a risk to be aware of at all times. All persons working in prisons are afraid of the suicide danger and are constantly under stress. Feeling the stress of the prisoners adds to their own stress. The persons working there do not know how to contain aggression and how to avoid it. Being in the prison does not allow any distance; and, violence seems to come from everywhere. This is so unbearable for certain guardians, that they commit suicide as well. They feel as if there are incarcerated in the same way as the prisoners and they suffer from "burn out" (Lourel, 2004). The situation becomes more and more dramatic and guardians frequently protest (Derrida, 1999; Le Monde 18 march 2013).

To give an idea about prisons in France: the population is about 60,000 prisoners, as large as a small suburb of Paris. $31.7 \%$ of the prisoners are incarcerated for preventative reasons, waiting for a judgment. $1.10 \%$ of the prisoners are minors. Prisoners are staying a longer time than before. In the $80 \mathrm{~s}$, the average time for incarceration was about 4.4 month. Today, it is nearly double, 8.4 month. Generally, prisons are crowed in France, the occupation varies from 100\% to 200\% (Falissard et al., 2006; Devilleres et al., 2000; Coldefy et al., 2002; Allilaire, 2009). In the prison of Fleury-Mérogis, there are currently approximately 5000 persons incarcerated. In the prison setting, all of the problems of society become magnified and the danger of suicide continues to grow.

\section{Suicides and Mental Health in Prison}

Losing freedom is part of the punishment; being incarcerated makes anyone unhappy (Compte-Sponville, 2000, 2010; Descartes, 2005; Foucault, 1995a, 1995b; Hatzenberger, 1999; Heidegger, 1980, 1987; Diderot, 2006; Freud, 1987; Hobbes, 1993). Even when, in some cases, prison life may have some positive effects in the patients' life (Balier, 2002, 2005; Bessoles, 2008, 2009a, 2009b; Auret \& Bessoles, 2008), the conditions (environmental, surroundings, hygienic) of prisons make it impossible to agree with this kind of punishment or treatment (Devillieres, Perez, \& Junot, 2000; Charbonneau, 2010; Tesu Rollier, 2006).

Psychiatrists are physicians who specialize in caring for the mental health of patients (American Psychiatric Association, 1952, 1968, 1980, 1997). A prisoner seen by the psychiatrist is a patient who has lost freedom. Being a psychiatrist in a prison setting is paradoxical: the environment of prison does not encourage favorable conditions for mental health or help to keep people healthy. Prescriptions of medicines, such as anti-depressants, anti-psychotics and narcoleptics should help individuals enjoy life, but work, family and love are very far away from individuals in prison. The patient will speak about his memory of social life as belonging to the past (Allilaire, 2009; Fédida \& Wolf-Fédida, 1995).

A psychiatrist has to conduct a medical examination of a new prisoner. He might have been ill before and may need his medication. There may be the risk of suffering again because incarceration changes the care of patients depending on medecine (Dejours et al., 1986, 2002; Dejours, 1999, 2003; Fédida, 1995, 2002a, 2002b, 2007). Following the medical evaluation when first incarcerated, the starting point in prison is to avoid misunderstanding. It is important not to mistake the consequences of the interruption of care with other symptoms that may be present (Tyrode et al., 1995; Kessler et al., 1995; Dubret, 2004, 2005).

A high score of major depression on an assessment instrument may suggest a “danger of suicide”. In addition, 
grief, stress and de-realization are widespread in prison. All symptoms-depression, anxiety, and even psychosis, need to be considered with caution and assessed by a clinician with experience in psychopathology.

It is possible that the prisoner might become ill in prison or show psychosomatic symptoms. But even for a prisoner who is not ill healthiness does not necessarily provide happiness in a hostile environment. Unhappiness when being healthy might be the starting point of depression (Fédida, 2001). The psychiatrist may believe that preventing suicide is also preventing depression.

Thus, the psychiatrist will aim more or less to prevent the worst by a passive approach-prescribing drugs (Gori \& Del Volgo, 2005; Allilaire, Harvey et al., 2005). In this way, one realizes that the practice of psychiatry is more radical in prison. The fear of death experienced by the incarcerated patient may lead to suicide. This fear is constantly present (Tesu-Rollier, 2013a, 2013b). A study at Fleury Mérogis over a period of ten years leads to the conclusion that there is a risk factor of $5 \%$ to $15 \%$ that a suicide attempt will finish (Andersen, 2004; Hivert, 1988) by completed suicide (Tesu-Rollier, 2012). This action is directed against the punishment-system and the guardians. Also, the guardians who felt stressed about it as a personal attack felt that they failed (Lourel, Gana, Prud'homme, Cercle et al., 2004).

In real life one should not depend on drugs because of the danger of addiction. But drugs help to escape everyday life. However, life in prison is artificial and drugs are an artificial solution to stay alive by being punished. So drugs seem to be more likely to be used with prisoners. Paradoxically, drugs help one feel more real: as the truth (of crime and punishment) is impossible to bear, drugs may help to keep one closer to life. Drugs help in a positive way in inspiring imagination and hope. This is a quality permitting a vision of a future (Loo \& Gourion, 2007; Andre, 2009; Sartre, 1996).

The prescriptions of psychiatrists in prison are ambivalent (Cohen \& Cailloux-Cohen, 1996). In prescribing, the psychiatrist has to care for the consequences of addiction. Addiction leads to experiences of strangeness and living in prison may also lead to this kind of experience. In everyday life, the psychiatrist would help to anticipate changes in the patients' life. But "inside" in prison, there are little possibilities to manage changes. The question about prescriptions and drugs, in an incarcerated environment, is different from normal life: might drugs keep one from other illnesses, psychosomatic diseases and mental troubles? They should help an individual withstand the situation. Moreover, "self-prescriptions" of the incarcerated persons by taking illegal drugs are very frequent. In a way, this resolves the psychiatrists' crisis of conscience.

Which is the best way to practice psychiatry in an environment hostile to mental life (isolation, crowded, violence, promiscuity)? Dr. D. Tesu-Rollier considers having incarcerated patients leads to new considerations about space and time in illness. Health and mental health are especially close to each other in an environment where there is no space (for intimacy, place is narrow) and a loss of time. Sports and communication are very important for one's mental health in prison (Tesu-Rollier, 2008). We may consider that incarceration leads to passivity and the prisoner reacts in a somatic way (Wolf-Fédida, 2010; Dejours, 1989, 1992).

The trouble with these kinds of "patients" is that all of them are confronted theoretically with the same risk of suicide. All of them have had the idea of suicide. When looking at statistics, $1 \%-2 \%$ out of 10,000 commits suicide and this is too much. Every life should be saved. But the psychiatrist is confronted with the statistical possibility (30\%) that suicide might be successful. The psychiatrist's aim is to keep these prisoners alive (Terra \& Seguin, 2003; HAS, 2005; Barrois, 1995).

Even if the circumstances are the same (punishment for crime by losing one's freedom), the reactions of individuals are difficult to compare. Health and illness are always related in a subjective way. Medicine explains health as the absence of illness. Technical progress shows that we carry a lot of illnesses that we should better ignore. There is no guarantee of stability in mental health (Binswanger, 2007; Canguilhem, 1966, 2000; Casoni \& Brunet, 2003). The fact of being in prison and having problems with the law questions one's mental stability. The prison environment leads to unpredictable behavior (Allialire, Pelissolo et al., 2005; Bergeret, 1997; Kernberg, 1989; Kessler, Sonnega, Bromet, Kessler, \& Nelson, 1995; Wolf-Fédida, 2009).

\section{Preventative Program and Comparison}

In our study, we investigated events in prison: working, learning, sports activities, walking in the court-yard (refusing, being isolated or in company), intercultural activities (speaking the mother tongue, searching for friends of the same culture). These data show that activity and sublimation by work, sports and friendships can be preventative and can be a starting point for a new life in prison (Tesu-Rollier, 2010). 
We wanted to know about conflicts coming from the outside and increasing in prison; illness before incarceration; and, mental problems represented by consulting a psychiatrist (Dubret, 2005; Ballier, 2002; Allilaire \& Thurin, 2002). This kind of information shows whether there is an influence of ancient problems or new problems that are from the outside (death of a parent, loss of somebody close, family quarrels) overwhelming the incarcerated person (Maïdi, 2003; Ciavaldini \& Balier, 2000). It is important to investigate whether illness first appears in prison or pre-existed. Illness might surface in one case and in other cases; the diagnosis of a chronic illness and a standard treatment will have a better chance for cure. That is the reason for investigating whether the incarcerated patient has seen a psychiatrist before and what problem motivated this consultation. There are depressed persons who ignore their feelings. They will not recognize themselves as being depressed because this is already a part of their being. In addition, every kind of mental suffering implies a part of depression. If the patient is aware of it and speaks about depression, he is not necessarily able to consider himself as borderline or psychotic. He will consider himself as somehow "neurotic" (Wolf-Fédida, 2009; Wolf-Fédida \& Fédida, 2005; Ey, 2000). Depression is often a part, a stage of another pathology. Information collected concerning the past might be altered by the appreciation of the present. Sorrow about what he has done and what happened might influence the person to give a new version about himself afterwards. Direct information given by the patient is helpful and interesting but needs interpretation by a specialist (Wolf-Fédida, 2010). In our work, we used different sources for data: government, OMS, associations and the clinical experience in the dispensary of psychiatry at Fleury-Mérogis (Coldefy, 2005; Cohen \& Cailloux-Cohen, 1996; Falissard, 2005; Falissard et al., 2006; Dubret, 2005; Guillonneau, 2003; HAS, 2005; OIP, 2001).

For example, the study of Fresnes, the second biggest prison in France, established statistics from 7000 of 12,000 consultations in SPMR; Service Médico-Psychologique Régionaux, Medical and Psychological Service of the Department) (Administration Services and Research of Administration Penitentiaries, 2003; Office of Persons placed under the Hand of Justice, PMJ1, PMJ2, 2000-2007). First, the study highlights personality disorders: $75 \%$. This might be the result of addiction to alcohol and drugs (benzodiazepine, ecstasy, and crack); $50 \%$ are addicted. Of course, addiction and disorders of personality are linked and it is difficult to know what was first. The study shows that depression is mainly represented ( $50 \%$ of the population) followed by psychotic troubles (25\%). Thus, depression is included with other difficulties (personality disorders, addiction, and psychosis) in this study. These statistics may give the idea that each incarcerated person suffers from psychological disturbances (Lamothe, 2001).

Forty percent (40\%) of incarcerated patients have seen a psychiatrist at least once (without taking into account the consultation of admission). Before prison, they saw the psychiatrist in the hospital or in consultation and some of them may have followed a special treatment. Once in prison the treatment is interrupted. Interrupting medical treatment can cause harm. The first French study about incarcerated patients in 1997 conducted by physicians showed that $30 \%$ of the arrivals consumed alcohol, tobacco, illegal drugs and psychotropics; and, $10 \%$ of the incarcerated persons were recommended to consult with a psychiatrist. The DREES study (Direction of Research, Investigation, Evaluation and Statistics of the Ministry of Health) with the French Group of Psychiatric Epidemiology (GFEP) conducted study in 2001 (published in 2002) in all Regional Medical and Psychological Services (SMPR) about 2302 new arrivals (Coldefy, Faure, \& Prieto, 2002; Cloninger, 2002; Coldefy, 2006). This time, the evaluation came from psychiatrists: $55 \%$ arrivals presented with at least one psychiatric disorder; $30 \%$ of men presented with a depressive disorder and $45 \%$ of women presented with a depressive disorder; $54 \%$ had addictive issues, $20 \%$ had been treated by psychiatry and $52 \%$ should have been treated for the difficulties that were detected. But finally only $10 \%$ were treated by psychiatry. The suicide risk for the $45 \%$ left seems high.

The study about arrivals indicates a high amount of psychopathology: anxiety (90\%), impulsivity (63\%), and addiction (35\%). Prevention of suicide could start with taking care of the difficulties and disorders detected. Even if they may be the expression of an existential crisis when arriving in prison, the unbearable nature of this situation may lead to a risk of suicide (Widlöcher, 1994, 1995; Winnicott, 2008a, 2008b; Walter \& Kermarrec, 1999).

Hetero and auto-aggression is very frequent, $70 \%$ for all kind of aggressions are mainly expressed by scarification. There are also hunger strikes, suicides attempts, self-inflicted injuries, auto-mutilations. Hunger strikes represent an auto-aggressive action. They are almost constant and it is difficult to consider them as equivalent to suicide because of the context (Fazel \& Danesh, 2002; Services administratifs et de Recherches de l'Administration Pénitentiaire, 2003; Barois, 1995). The scientific community from North America and Canada thought more about the finality of the act when considering hunger strikes as equivalent to suicide. But it may also be a kind of escape. Indeed, this is a problem about evaluation (Tron \& Loas, 2000). Should we explain every ex- 
pression as an individual form of statement or should we look for the consequences?

In France, on the one hand, psychiatrists are confronted with a law ordering them to respect the autonomy of the prisoner. On the other hand, they are ordered to save lives. The situation of hunger strikes requires an individual consideration (Ley, 1974). For each prisoner-patient, we have to evaluate if refusing food is a protest or if the person is entering into a pathological, critical situation and needs to be helped (INSERM, 2006; Kinsey, 2006). This situation states that auto-mutilation is a scream for help, whereas a hunger strike is meant to be a willing act of protest and has to be respected. Prevention of suicide enters more likely into action in the case of a hunger strike in prison because the psychiatrist is aware of the frequency of suicide attempts. Speaking and signifying by words what happens to the person is a start towards prevention (Kohut, 1974; Lanteri-Laura, 1997; Lighezollo \& de Tyché C. 2004). He will speak in a way or another about the need of liberty, of individual choice and the longing for evasion. No doctor can "heal" somebody who does not ask for it. Psychiatrist must be careful when considering the incarcerated person as ill in this case. This attitude may make him much more ill. So the psychiatrist has to be aware of the kind of health-system he wants to promote in prison. Preventing suicide means respecting individuality and considering the meaning of subjectivity.

Comparing statistics we may wonder about the period when suicide occurs just after incarceration (Cohen, 2008; Coutanceau, 1997; Dejours, 1998; Gasman \& Allilaire, 2003; Goldstein, 1987). Indeed, the highest rate happens with new arrivals, just when they stay with accusation without judgment. We have to be impressed by this high score compared to those incarcerated after judgment. Thus, the beginning of prison time is the most risky for suicide. Another surprise is to realize that suicide happens also at the end of incarceration. We understand that the incarcerated person without hope to get liberty one day wants to finish and suicide.In fact, the risk never vanishes (Maïdi, 2003; Minkowski, 2004; Maldiney, 1991; Murphy et al., 2000; Petitclerc, 2005; Scherer, 2000; Schweitzer \& Puig-Verges, 2001; Seguin \& Terra, 2003; Kensey, 2006). But we wonder about those who suicide before the near liberation. It is as if they experience their incarceration as being there for life and changes are unbearable-in the same way as for new arrivals. Subjectivity and facts are confused: inside, outside, past and future in relation to oneself and others. It is important to speak about the subjective meaning of getting into prison and of coming out. Being a psychiatrist in prison is less about getting the patient reasonable than giving sense to a subject (Tesu-Rollier, 2013a, 2013b).

\section{Conclusion}

We should investigate the different periods of prison time in the same way as studies of sorrow. First, the statistics let us conclude that prevention of suicide must start as soon as possible when arriving, hoping that the effort in the beginning creates a more healthy mental state for later. Second, it is troubling to realize that a person gives up when liberty is so near. The DREES study also showed that any kind of change that happens in prison (a new room, sharing with a new person, moving to another wing) is troubling and may lead to crisis. We have seen that reintroducing the human factor is important when considering everyday life in prison. Verbalizing about feelings is necessary for incarcerated persons as well as for the persons working there. Activities, sports and contact with culture and knowledge are intellectual and emotional stimulation. Furthermore, maintaining contact with one's culture and one's mother-language is important for psychic well being (Wolf-Fédida \& Tesu-Rollier, 2010; Romila, 2005; Salas, 2005).

\section{References}

Allilaire, J. F. (2009). Cognitive Avoidance of Intrusive Memories and Autobiographical Memory: Specificity, Autonoetic Consciousness, and Self-Perspective. In Memory (pp. 1-7), Paris: Elsevier.

Allilaire, J. F., \& Harvey, P. O. et al. (2005). Cognitive Control and Brain Resources in Major Depression: An fMRI Study Using the N-Back Task. In Neuroimage (pp. 860-869). Paris: Elsevier.

Allilaire, J. F., \& Thurin, J. M. (2002). Psychopathologie et traitements actuels des auteurs d'agressions sexuelles. Paris: HAS.

Allilaire, J. F., Pelissolo, A. et al. (2005). The Temperament and Character Inventory-Revised (TCI-R): Psychometric Characteristics of the French Version. In Acta Psychiatrica Scandinavian (pp. 126-133). New York: Wiley.

Allilaire, J. F. (2005). Psychiatrie de l'adulte, de l'enfant et de l'adolescent. Paris: Masson.

American Psychiatric Association (1952). Diagnostic and Statistical Manual of Mental Disorders. Washington: American Psychiatric Association. 
American Psychiatric Association (1968). Diagnostic and Statistical Manual of Mental Disorders. Washington: American Psychiatric Association.

American Psychiatric Association (1980). Diagnostic and Statistical Manual of Mental Disorders. Washington: American Psychiatric Association.

American Psychiatric Association (1997). Diagnostic and Statistical Manual of Mental Disorders. Washington: American Psychiatric Association.

Andre, C. (2009). Dépression et régulation des emotions. Paris: Editions Scientifiques.

Auret, A., \& Bessoles, P. (2008). Interfaces cliniques et juridiques. Grenoble: PUG.

Balier, C. (2002). Psychanalyse des comportements violents. Paris: PUF.

Balier, C. (2005). La violence en abyme. Paris: PUF.

Barois, C. (1995). Les comportements violents. Paris: PUF.

Bergeret, J. (1997). La personnalité normale et pathologique. Paris: Dunod.

Bessoles, P. (2008). Viol et identité. Un genocide individuel. Paris: MJW Fédition.

Bessoles, P. (2009a). Criminalité et récidive. Grenoble: PUG.

Bessoles, P. (2009b). Sciences criminelles cliniques. Paris: MJW Fédition.

Binswanger, L. (2007). Discours, parcours et Freud. Paris: PUF.

Canguilhem, G. (1966). Le normal et le pathologique. Paris: PUF.

Canguilhem, G. (2000). Le normal et le pathologique. Paris: PUF.

Casoni, D., \& Brunet L. (2003). La psychocriminologie. Montréal: PUM.

Charbonneau, G. (2010). Introduction à la psychopathologie phénoménologique. 1 \& 2, Paris: MJW Fedition.

Ciavaldini, A., \& Balier, C. (2000). Agressions sexuelles: Pathologies, suivis thérapeutiques et cadre judiciaire. Paris: Masson.

Cloninger, R. (2002). Handbook of Quotations and Scales for Assessment of the Personality. Paris: Masson.

Cohen, D. (2008). Pédiatrie, Psychiatrie de l'enfant et de l'adolescent. Paris: Vernazobres.

Cohen, D., \& Cailloux-Cohen, S. (1996). Guide critique des médicaments de l'âme. Paris: AGIDD-SMQ.

Coldefy, M. (2005). La prise en charge de la santé mentale des détenus en 2003. Etudes et résultats, No. 427, Ministère de la Santé.

Coldefy, M. (2006). La prise en charge de la santé mentale des détenus en 2004. Etudes et résultat, Ministère de la Santé.

Coldefy, M., Faure, P., \& Prieto, N. (2002). La santé mentale et le suivi psychiatrique des détenus accueillis par les services médico-psychologiques régionaux. Ministère des affaires sociales, du travail et de la solidarité, Ministère de la santé, de la famille et des personnes handicapées, DREES. Etudes et résultats, No. 181.

Compte-Sponville, A. (2000). La liberté. Paris: O. Jacob.

Compte-Sponville, A. (2010). Le goût de vivre et cent autres propos. Paris: Albin Michel.

Coutanceau, R. (1997). Etude d'un cas. In Forensic: Revue de psychiatrie et psychologie légales (pp. 1-2). Paris: Elsevier.

Dejours, C. (1986). Le corps entre biologie et psychanalyse. Paris: PUF.

Dejours, C. (1989, 1992). Les dissidences du corps. Paris: Payot.

Dejours, C. (1998). Souffrance en France, la banalisation de l'injustice sociale. Paris: Seuil.

Dejours, C. (1999). Le facteur humain. Paris: Dunod.

Dejours, C., Debruy, R., \& Fédida, P. (2002). Psychopathologie de l'expression du corps. Paris: Dunod.

Derrida, J. (1999). Donner la mort. Paris: Gallilée.

Devillieres, P., Perez, S., \& Junot, A. (2000). Interfaces Psychiatriques-Justice: Nouvellesexigences. In Revue Française de Psychologie médicale (pp. 35-37). Paris: EditionsMF.

Diderot, D. (2006). Essai sur le mérite et la vertu. Paris: ALIVE.

Dubret, G. (2004). L'expertise psychiatrique et les experts «psys». Pluriels, Lettre de la mission nationale d'appui en Santé mentale. Ministère de la Santé, 28.

Dubret, G. (2005). L'expertise psychiatrique et les experts «psys». Pluriels, Lettre de la mission nationale d'appui en Santé mentale. Ministère de la Santé, 29.

Ey, H. (2000) Schizophrénie, Etudes cliniques et psychopathologiques. Paris: Synthélabo. 
Falissard, B. (2005). Comprendre et utiliser les statistiques dans les sciences de la vie. Paris: Masson.

Falissard, B. et al. (2006). Prévalence des troubles mentaux dans les prisons françaises pour homes. BMC Psychiatry,6, 33.

Fazel, S., \& Danesh, J. (2002). Serious Mental Disorder in 23000 Prisoners: A Systematic Review of 62 Surveys. Lancet 359, 545-550.

Fédida, P. (1995). L'absence. Paris: PUF.

Fédida, P. (2002a). Préface. In H. Searles (Ed.), L'effort pour rendre l'autre fou (pp. 11-51). Paris: Gallimard.

Fédida, P. (2002b). Les bienfaits de la dépression. Paris: O. Jacob.

Fédida, P. (2007). Humain/Deshumain, Pierre Fedida la parole de l'oeuvre. Paris: PUF.

Foucault, M. (1995a). Surveiller et punir. Paris: Gallimard.

Foucault, M. (1995b). Histoire de la folie à l'âge classique. Paris: Gallimard.

Freud, S. (1987). Au-delà du principe de plaisir. In Essais de psychanalyse (pp. 2-57). Paris: Payot.

Gasman, I., \& Allilaire, J. F. (2003). Psychiatrie de l'enfant, de l'adolescent et de l'adulte. Paris: Masson.

Goldstein, J. (1987). Consoler et classifier. L'essor de la psychiatrie française. Le plessis Ronbinson: Synthélabo.

Gori, R., \& Del Volgo, M. J. (2005). La santé totalitaire, Essais sur la médicalisation de l'existence. Paris: Denoël.

Guillonneau, M. (2003). 2001-2002 Suicides et caractéristiques des établissements pénitentiaires. Paris: Rapport, Direction de l'Administration Pénitentiaire.

Andersen, H. S. (2004). Mental Health in Prison Populations. A Review-With Special Emphasis on a Study of Danish Prisoners on Remand. Acta Psychiatrica Scandinavica, 110, 5-59.

HAS, Haute Autorite de la Santé (2005). Prise en charge de la psychopathie. Paris: Ministère de la Santé.

Hatzenberger, A. (1999). La liberté. Paris: Flammarion.

Heidegger, M. (1980). Etre et temps. Paris: Gallimard.

Heidegger, M. (1987). De l'essence de la liberté humaine, Introduction à la philosophie. (tr. Martineau E.) Paris: Gallimard.

Hivert, P. (1988). Psychiatrie en milieu carcéral. Encylopédie Médicale Chirurgicale, Article No. 37889A10.

Hobbes, T. (1993). De la liberté et de la nécessité. Paris: Flammarion.

INSERM (2006). Unity of Care Alimentation Comportements. University Paris XI. BMC Psychiatry, 15, 139-145.

Kensey, A. (2006). Prison et récidive. Paris: Armand Colin.

Kernberg, O. (1989). Les troubles graves de la personnalité: Stratégies psychothérapiques. Paris: PUF.

Kessler, R. C., Sonnega, A., Bromet E., Hughes, M., \& Nelson, C. B. (1995). Postraumatic Stress Disorder in the National Comorbidity Survey. Archives of General Psychiatry, 52, 1048-1060.

Kohut, H. (1974). Le Soi. Paris: PUF.

Lamothe, P. (2001). Psychopathie «américaine» et psychopathie «française»: Une confrontation clinique et culturelle». L'Évolution Psychiatrique, 66, 602-608.

Lanteri-Laura, G. (1997). La chronicité en psychiatrie. Paris: Synthelabo.

Ley, A. (1974). Le refus de manger, dit grève de la faim chez les prisonniers. In Revue de Droit Pénal et Criminel (pp. 485-488). Paris: Dalloz.

Lighezollo, J., \& de Tyché, C. (2004). La résilience: Se (re)construire après le traumatisme. Paris: In Press.

Loo, H., \& Gourion, D. (2007). L'ennemi de l'âme, guérir de la depression. Paris: Odile Jacob.

Lourel, M., Gana, K., Prud'homme, V., \& Cercle A. (2004). Le burnout chez le personnel des Maisons d'Arrêt: Test du modèle « demande-contrôle » de Karasek. Encéphale, 30, 557-563.

Maïdi, H. (2003). La plaie et le couteau. Et si la victime était son bourreau. Genève: Delachaux et Niestlé.

Maldiney, H. (1991). Penser l'homme et la folie. A la lumière de l'analyse existentielle et de l'analyse du destin. Grenoble: J. Million.

Minkowski, E. (2004). Traité de psychopathologie, Introduction de Georges Lanteri-Laura. Paris: Synthélabo.

Murphy, J. M., Morrison, R. R., Laird, N. M., Sobol, A. M. \& Leighton, A. H. (2000). A Comparison of Diagnostic Interview for Depression in the Stirling County Study: Challenges for Psychiatric Epidemiology. Archives of General Psychiatry, 57, 230-236.

Office of Persons Placed under the Hand of Justice, PMJ1, PMJ2 (2000-2007). Regional Direction of Penitenciary Administration.

OIP (2001) Observatoire International des Prisons. Le nouveau guide du prisonnier. Paris: Les éditions de l’Atelier. 
Petitclerc, J. M. (2005). Et si on parlait du suicide des jeunes? Paris: Presses de la Renaissance.

Prieto, N., \& Faure, P. (2004). The Mental Health of New Prisoners or of Those Monitored in French Prisons with "services medico-psychologiques régionaux” (SMPR). In Encéphale (pp. 525-531). Paris: Elsevier Masson.

Romila, A. (2005). Traité de Psychiatrie. Bucarest: APLR.

Salas, D. (2005). La volonté de punir. Paris: Hachette.

Sartre, J. P. (1996). L'être et le néant. Paris: Gallimard.

Scherer, K. R. (2000). Psychological Model of Emotion. In J. Borod (Ed.), The Neuropsychology of Emotion (pp. 137-162). Oxford: Oxford University Press.

Schweitzer, M. G., \& Puig-Verges, N. (2001). Troubles psychiques, discernement et passage à l'acte, Une difficulté méthodologique. In J. Libbey (Ed.), Information Psychiatrique (pp. 487-491). Montrouge: John Libbey Eurotext.

Seguin, M., \& Terra, J. L. (2003). Formation à l'intervention de crise suicidaire, Manuel du formateur. Lyon: Ministère de la santé.

Services administratifs et de Recherches de l’Administration Pénitentiaire (2003). Revue d'information et de présentation. Fresnes: Direction Régionale de l’Administration Pénitentiaire.

Terra, J. L. \& Seguin, M. (2003). Prévention du suicide des personnes détenues, évaluation des actions mises en place et propositions pour développer un programme complet de prévention. Paris: Ministère de la Justice et Ministère de la Santé de la Famille et des Personnes Handicapées.

Tesu-Rollier, D. D. (2008). Sport et alliance thérapeutique en milieu carcéral. Annales médico-psychologiques. Revue psychiatriques, 166, 865-869.

Tesu-Rollier, D. D. (2013a). Le deuil en prison. Annales médico-psychologiques. Revue psychiatriques, 171, 196.

Tesu-Rollier, D. D. (2013b). Troubles sexuels et prévention du suicide en milieu carcéral. Annales médico-psychologiques. Revue psychiatriques, $171,115-117$.

Tesu-Rollier, D. D., \& Coutanceau, R. (2007). Clinique et psychopathologie en milieu carcéral. A propos d’une expérience de pratique à la Maison d’Arrêt de Fleury-Mérogis. Annales médico-psychologiques. Revue psychiatriques, 165, 8-12.

Tron, P., \& Loas, G. (2000). De la fiabilité des expertises: Etude comparative sur des patients hospitalisés ou emprisonnés après un acte criminel. Annales Médico-Psychologiques, 150, 741-746.

Tyroge, Y., \& Albernhe, T. (1995). Psychiatrie légale, sociale, hospitalière, expertale. Paris: Ellipses.

Walter, M., \& Kermarrec, I. (1999). Idées ou conduites suicidaires: Orientation diagnostique et conduite à tenir en situation d’urgence. Revue du Praticien, 49, 1685-1690.

Widlöcher, D. (1994). Traité de psychopathologie. Paris: PUF.

Widlöcher, D. (1995). Les logiques de la depression. Paris: Fayard.

Winnicott, D. W. (2008a). L’Effondrement de la construction. Revue française de Psychanalyse, 66, 166-167.

Winnicott, D. W. (2008b). Généalogie de la problématique suicidaire. Evolution Psychiatrique, 73, 273-274.

Wolf-Fédida, M. (2009). Psychopathologie fondamentale, suivie de l'Abécédaire de Pierre Fedida. Paris: MJW Fédition.

Wolf-Fédida, M. (2010). Bilinguisme et Psychopathologie. Paris: MJW Fédition.

Wolf-Fédida, M., \& Fédida, P. (2005) Phénoménologie, psychiatrie, psychanalyse. Paris: Le Cercle herméneutique. 
Scientific Research Publishing (SCIRP) is one of the largest Open Access journal publishers. It is currently publishing more than 200 open access, online, peer-reviewed journals covering a wide range of academic disciplines. SCIRP serves the worldwide academic communities and contributes to the progress and application of science with its publication.

Other selected journals from SCIRP are listed as below. Submit your manuscript to us via either submit@scirp.org or Online Submission Portal.
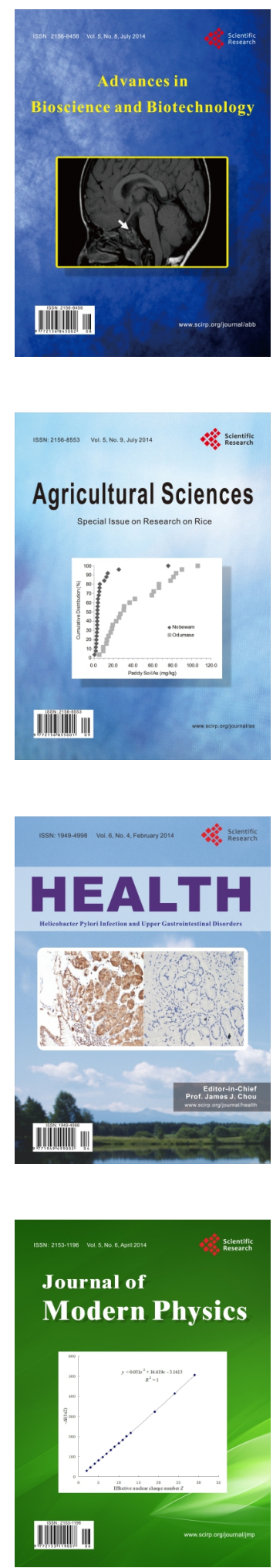
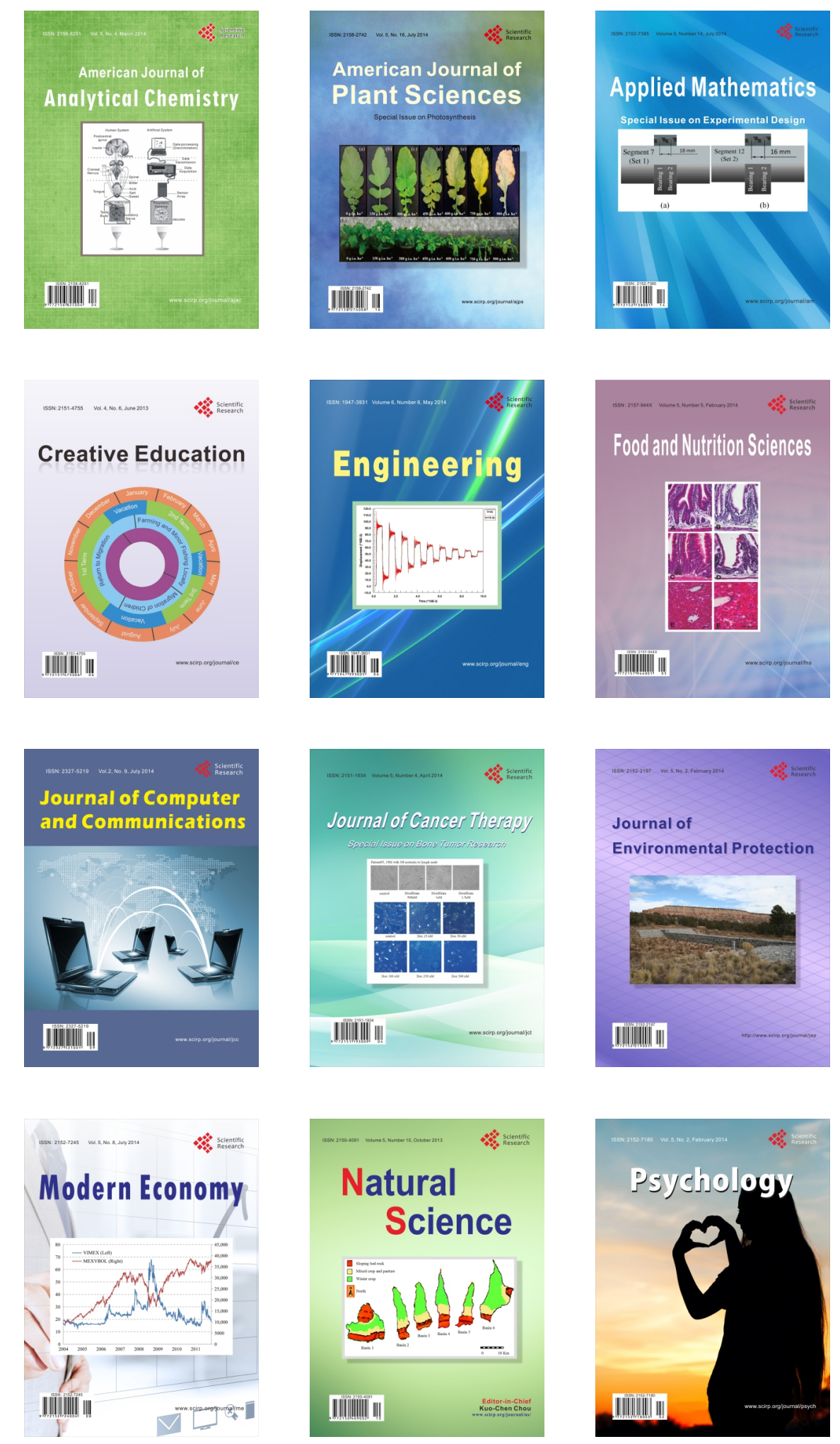